\title{
Neurotrophin-4/5 (NT-4/5) and Brain-Derived Neurotrophic Factor (BDNF) Act at Later Stages of Cerebellar Granule Cell Differentiation
}

\author{
Wei-Qiang Gao, J. Lisa Zheng, and Mona Karihaloo \\ Department of Neuroscience, Genentech, Inc., South San Francisco, California 94080
}

The developing cerebellum expresses genes which encode for both neurotrophins and their receptors. The present study was designed to determine at what stages during cerebellar granule cell neurogenesis neurotrophin family molecules may act. We report here that in purified, wellcharacterized granule cell cultures (Gao et al., 1991; 1992), none of the neurotrophins stimulated proliferation of granule cell precursors or rescued phenotypic defect of mutant weaver granule cell precursors in the initiation of neuronal differentiation. However, neurotrophin-4/5 (NT-4/5) and BDNF, but not neurotrophin-3 (NT-3) or NGF, promoted neurite extension and survival of differentiated cerebellar granule cells. Both of these effects were blocked by the specific inhibitor for Trk tyrosine kinases, K-252a. NT-4/5 and BDNF also enhanced neurite extension by weaver granule cells which were rescued by wild-type granule cells during differentiation. Moreover, TrkB immunohistochemistry performed on sections of the developing wildtype and weaver cerebella revealed that only differentiated granule cells, but not the precursor cells, make high levels of TrkB receptor. These findings together suggest that NT4/5 and BDNF promote the maturation and maintenance of differentiated granule cells, effects which are downstream to the weaver gene. Since no additive effects were seen with the combination of NT-4/5 and BDNF, it seems likely that the two neurotrophins activate the same receptor trkB for signal transduction.

[Key words: external germinal layer, weaver, neuronal proliferation, neurite extension, neuronal survival, $K-252 a$, TrkB immunohistochemistry]

The cerebellar granule neuron has provided an opportune model system for studies on mammalian CNS neurogenesis as it is generated in a displaced zone, the external germinal layer (EGL), in the postnatal cerebellum (Ramon y Cajal 1889, 1911). While cells in the superficial zone of the EGL are mitotic (Miale and Sidman, 1961; Fujita et al., 1966; Fujita, 1967; Altman, 1972), cells in the deep EGL start to undergo an initial phase of neuronal differentiation by extension of long parallel fibers ( $R \mathbf{a}$ -

\footnotetext{
Received Mar. 30, 1994; revised Oct. 19, 1991; accepted Oct. 21, 1994.

We thank Drs. Stuart Feinstein and Monte Radeke for their gifts of TrkB antisera; Karoly Nikolics, Arnon Rosenthal, and Randall Stewart for critical reading of the manuscript; and Xueming Qian for helpful discussions.

Correspondence should be addressed to Dr. Wei-Qiang Gao, Department of Neuroscience, MS \#72, Genentech, Inc., 460 Point San Bruno Boulevard, South San Francisco, CA 94080.

Copyright $(\mathcal{1} 1995$ Society for Neuroscience $\quad 0270-6474 / 95 / 152656-12 \$ 05.00 / 0$
}

mon y Cajal, 1889, 1911; Gao and Hatten, 1993). After migration along Bergmann glial fibers (Rakic, 1971; Edmondson and Hatten, 1987; Gregory et al., 1988; Hatten, 1990, Gao and Hatten, 1993) and passing through the molecular layer and Purkinje cell layer, the granule cells position themselves in the internal granule cell layer where they mature by the extension of peculiar neuritic arborizations (Ramon y Cajal, 1889, 1911; Gao and Hatten, 1993).

The characteristic morphology, cell size, and large number of EGL granule cell precursors in the early postnatal mouse has allowed their purification for in vitro analyses (Hatten, 1985, 1987; Gao et al., 1991, 1992). The purified EGL cells express immunocytochemical, cytological and ultrastructural features of immature granule cells in vitro (Hatten, 1985, 1987; Gao et al., 1991) and assume the identity of granule neurons after they are implanted into the developing cerebellum in vivo (Gao and Hatten, 1994).

Another advantage of working with the cerebellum is the availability of ncurological mutant mice. In one particular mu tant mouse called weaver, cerebellar granule cell precursors proliferate normally in the superficial layer of the EGL (Rezai and Yoon, 1972), but fail to initiate neuronal differentiation. These mutant cells fail to extend neurites (Willinger and Margolis, 1985; Gao et al., 1992; Gao and Hatten, 1993) or migrate away from the EGL (Rakic and Sidman, 1973; Sotelo and Changeux, 1974; Hatten et al., 1984; Gao and Hatten, 1993). As a result, this mutant cerebellum serves as a good system to study signals for initiation of neuronal differentiation (Gao et al., 1992).

The highly restricted spatial pattern of dividing and differentiating cells in the EGL suggests that epigenetic signals regulate neuronal proliferation and neuronal differentiation in the developing cerebellum. By taking advantage of the ability to purify the EGL cells, we have previously been able to reconstitute the EGL of the developing cerebellum by reaggregating the purified EGL cells in vitro to study mammalian CNS neurogencsis (Gao et al., 1991, 1992). For example, we have demonstrated that cell-cell interactions among FGI granule cell precursors promote neuronal proliferation and allow the EGL precursor cells to continue to divide for a prolonged time (Gao et al., 1991). When the reaggregated EGL cells are transferred to a poly-D-lysine substrate, they rapidly undergo neuronal differentiation by extending a halo of neurites (Gao et al., 1991). By mixing weaver and wild-type EGL precursor cells in the reaggregate culture system, we found that a membrane-bound signal encoded by the weaver gene in wild-type EGL cells rescues the weaver cell phenotype by inducing the mutant cells to undergo neurite extension and neuronal migration along glial fibers (Gao 
et al., 1992). In addition, the implantation of weaver EGL cells into the developing wild-type cerebellum confirmed that the weaver cells can he rescued by local signals in the developing wild-type cerebellum to undergo neuronal differentiation (Gao and Hatten, 1993). These experiments together indicate that the weaver gene acts at the initial stages of granule cell differentiation.

The neurotrophin family which includes NGF (Levi-Montalcini and Angeletti, 1968), BDNF (Barde et al., 1982; Leibrock et al., 1989), NT-3 (Ernfors et al., 1990; Hohn et al., 1990; Jones and Reichardt, 1990; Maisonpierre et al., 1990; Rosenthal et al., 1990), and NT-4/5 (Berkemeier et al., 1991; Ip et al., 1992) has been implicated in the regulation of neuronal proliferation and differentiation during neurogenesis (Patterson, 1978; Anderson, 1989; Cattaneo and McKay, 1990; Rosenthal et al., 1990; DiCicco-Bloom et al., 1993; Henderson et al., 1993). Indeed, these ncurotrophins and their receptors have been reported to be widely distributed in the developing cerebellum (Hofer et al., 1990; Klein et al., 1990; Maisonpierre et al., 1990; Ernfors et al., 1992; Rocamora et al., 1993; Timmusk et al., 1993). However, the stages these neurotrophins act at during neurogenesis have not been well-demonstrated for cerebellar granule cells. The present experiments were designed to determine the possible influence of the four neurotrophin family members on four stages of cerebellar granule cell neurogenesis including proliferation, initiation of differentiation, maturation, and maintenance. We report here that none of the neurotrophins stimulated neuronal proliferation or induced neuronal differentiation of weaver EGL cells. However, NT-4/5 and BDNF, but not NT-3 or NGF, promoted neurite extension and survival of differentiated granule cells. NT-4/5 and BDNF also enhanced neurite extension of weaver granule cells which were first rescued by wildtype granule cells in the initiation of neuronal differentiation. In addition, TrkB antibody labeling on postnatal wild-type and weaver cerebellar sections indicate that only differentiated granule neurons, but not the precursor cells, make high levels of TrkB protein which is the high affinity receptor for BDNF and NT-4/5 (Klein et al., 1990, 1991; Berkemeier et al., 1991; Ip et al., 1992, 1993). These experimental data suggest that while the weaver gene acts at the initial stagc of granulc ccll differentiation, NT-4/5 and BDNF play a trophic role for maturation and maintenance of differentiated granule cells.

\section{Materials and Methods}

Purification of cerebellar EGL cells. EGL cells were purified from C57B1/6 mouse cerebella on postnatal days 5-6 (P5-P6) when EGL was abundant, as described previously (Hatten, 1985, 1987; Gao et al., 1991). To obtain virtually pure populations of cells, a granule cell fraction was separated with a step gradient of Percoll, and EGL cells were purified by preplating the granule cell fraction on a poly-D-lysine-treated substrate two or three times (30-40 min each).

Some of the experiments were carried out with EGL cells purified from homozygous weaver B6CBA-A ${ }^{w}-J_{-} w v$ ( $\left.w v / w v\right)$ mouse cerebella harvested on P5-P6. Weaver $(w v / w v)$ cerebella were identified by their smaller overall dimensions, especially at the midline, and smaller number of folia (Rakic and Sidman, 1973). The medial third of weaver (wiv/ $w v$ ) cerebella on either side of the midline was dissociated into a single cell suspension (Hatten et al., 1986) and EGL cells were purified as described (Gao et al., 1991, 1992).

Cell cultures. For reaggregate cultures, freshly harvested EGL cells were plated in uncoated Nunc 16-well Lab-Tek culture slides (approximately $2 \times 10^{6} \mathrm{cells} /$ well) in either serum-supplemented medium (see Gao et al., 1991; BME plus $10 \%$ horse serum, $5 \%$ fetal bovine serum, $9 \mathrm{mg} / \mathrm{ml}$ glucose, $0.3 \mathrm{mg} / \mathrm{ml}$ glutamine, $50 \mathrm{U} / \mathrm{ml}$ penicillin, and $50 \mu \mathrm{g} /$ $\mathrm{ml}$ streptomycin) or serum-free medium (see Henderson et al., 1993; L- 15 plus $0.2 \mathrm{~nm}$ progesterone, $0.1 \mathrm{~mm}$ putrescine, $0.1 \mathrm{mg} / \mathrm{ml}$ ovotrans- ferrin, $5 \mu \mathrm{g} / \mathrm{ml}$ insulin, $2 \mathrm{mg} / \mathrm{ml}$ glucose, $22.5 \mathrm{~mm}$ sodium bicarbonate, and $50 \mathrm{U} / \mathrm{ml}$ penicillin and $50 \mu \mathrm{g} / \mathrm{ml}$ streptomycin).

For monolayer cell cultures, 100,000 cells were plated in $35 \mathrm{~mm}$ Nunc tissue culture dish pretreated with poly-D-lysine $(1 \mathrm{mg} / \mathrm{ml})$. Cultures were maintained in serum-free medium (see above) in the absence or presence of different neurotrophins.

DNA synthesis assays. To measure ${ }^{3} \mathrm{H}$-thymidine incorporation, an identical number of cells $\left(5 \times 10^{5}\right)$ were plated in 96 well plates in the serum-free medium in the absence or presence of different neurotrophins, ${ }^{3} \mathrm{H}$-thymidine $(1 \mu \mathrm{Ci} /$ well $)$ was added for $21 \mathrm{hr}$ at $24 \mathrm{hr}$ of culture, and cells were harvested using a Tomtec cell harvester. $\mathrm{Cpm} /$ well were then counted with a matrix 9600 gas counter (Packard Instrument Company, Downers Grove, IL).

Bromo-deoxyuridine (BrdU) immunocytochemistry. BrdU labeling was performed by a modification of Gratzner (1982) as described previously (Gao et al., 1991). The cell reaggregates were cultured in 16 well Lab-tek culture slides in the serum-free medium in the absence or presence of $10 \mathrm{ng} / \mathrm{ml}$ l of different neurotrophins. After $1 \mathrm{~d}$, BrdU (1: 200; Boehringer cell proliferation kit) was added to the culture medium for $21 \mathrm{hr}$, after which the cells were fixed in $100 \%$ ethanol containing $5 \%$ acetic acid $(20 \mathrm{~min})$, treated with $2 \mathrm{~N} \mathrm{HCl}(40 \mathrm{~min})$, and incubated with an anti-BrdU monoclonal antibody (Boehringer; 1:10 in phosphate buffered saline containing $0.1 \%$ Triton $\mathrm{X}-100)(2 \mathrm{hr})$. The cultures were then incubated with a biotinylated sheep anti-mouse secondary antibody $(1: 200)$ and a streptavidin horseradish peroxidase conjugate $(1: 200$, Amersham Life Science) for $30 \mathrm{~min}$ each. After diaminobenzidineperoxidase reaction, the cells were dehydrated with ethanol, cleared in xylene and mounted in Permount (Fisher). The mitotic index was measured by counting the pcrcentage of labeled cells with Nomarski optics, at different optical planes within the reaggregate. For each value, a random sample of 2000 cells was counted, as described (Gao et al., 1991).

The same mitotic assay was performed on low cell density, monolayer cell cultures $(100,000$ cells $/ 35 \mathrm{~mm}$ dish) that were also used for examinations of cell survival.

Coculture of weaver EGL cells and wild-type EGL cells in cellular reaggregates. As previously described (Gao et al.. 1992; Gao and Hatten, 1993), freshly purified weaver EGL cells were resuspended in $1 \mathrm{ml}$ of diluent solution (Cell linker kit, Sigma) and mixed with $1 \mathrm{ml}$ of 2 $\mu \mathrm{M}$ PKH26 (provided by the manufacturer), after which the cells were mixed by pipetting ( $3 \mathrm{~min}$ ). The reaction was stopped by the addition of $2 \mathrm{ml}$ of serum ( $1 \mathrm{~min}$ ). The cells were then diluted with an equal volume of seruin-supplemented culture medium, and washed $(3 \times)$ by centrifugation. Dye-labeled weaver cells were counted, mixed at a ratio of 1:10 with unlabeled wild-type cells and plated in reaggregate cultures as described (Gao et al., 1992).

Quantitation of neurite extension by cellular reaggregates. For neurite extension assays, after $24-48 \mathrm{hr}$ in culture, cellular reaggregates were transferred to a 8-well plastic Lab-Tek culture slide treated with poly-D-lysine $(1 \mathrm{mg} / \mathrm{ml})$ in serum-free medium (see above) as previously described (Gao et al., 1992). All processes extended from the reaggregates could be stained by a monoclonal antibody against neurofilament protein (data not shown) as these were purified cells. Following fixation of the cultures in $2 \%$ glutaraldchyde in $0.1 \mathrm{M}$ phosphate buffer ( $\mathrm{pH} 7.4$ ) for $1 \mathrm{hr}$, neurite extension was quantitated by measuring the distance from the perimeter of the neurites to the edge of the reaggregate. We took an average measurement of each reaggregate at four different points (both vertically and horizontally). For each of the experimental groups, data were collected from $30-40$ different reaggregates with similar size from three to five cultures.

Cell counts. For the monolayer, low density cultures, viable cells were identified through trypan blue exclusion under a phase contrast microscope, and counted using a grid ocular reticule covering an area of $1 \mathrm{~mm}^{2}$. For each culture, $10-20$ fields were counted. Data were collected from three to five cultures for each of the experimental groups.

Growth factors and K-252a. All neurotrophins (Genentech, Inc.) were added to the cultures at the time of plating or at the time when the cellular reaggregates were transferred to a poly-D-lysine substrate. To block the effects of the neurotrophins, $100 \mathrm{nM}$ of K-252a (Calbiochem, San Diego, CA), a specific inhibitor for Trk tyrosine kinase receptors (Berg et al., 1992; Nye et al., 1992; Tapley et al., 1992), was added to some of the experimental cultures at the same time when neurotrophins were added. In other experiments, bFGF $(10 \mathrm{ng} / \mathrm{ml})$, which was previously shown to promote granule cell survival (Hatten et al., 1988; Cohen et al., 1990), was added to the culture along with K252a to dem- 


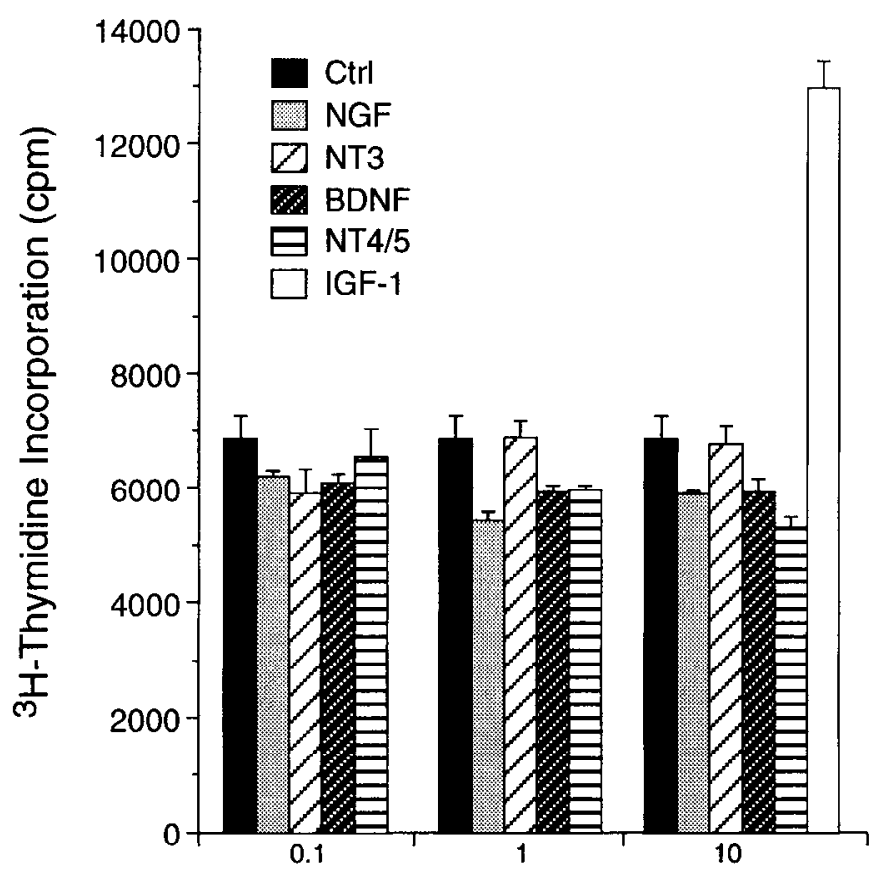

Concentration of growth factors $(\mathrm{ng} / \mathrm{ml})$

Figure 1. Neurotrophins do not stimulate ${ }^{3} \mathrm{H}$-thymidine incorporation by P5-P6 EGL granule cell precursors in the reaggregate cultures. In each case, an identical number of EGL cells $\left(5 \times 10^{5}\right)$ were plated in serum-free medium in the absence or presence of different neurotrophins or IGF-1. ${ }^{3} \mathrm{H}$-Thymidine was added $24 \mathrm{hr}$ after plating and incorporation was measured $21 \mathrm{hr}$ later. Data from triplicate cultures are expressed as mean \pm SEM. In contrast to IGF- 1 which induced a nearly twofold increase (at a concentration of $10 \mathrm{ng} / \mathrm{ml}$ ), none of neurotrophins stimulated the ${ }^{3} \mathrm{H}$-thymidine incorporation by the EGL cells.

onstrate that $100 \mathrm{nM}$ of $\mathrm{K} 252 \mathrm{a}$ was not toxic to these cells and to confirm that $\mathrm{K} 252 \mathrm{a}$ was a specific Trk tyrosine kinase inhibitor.

TrkB immunohistochemistry. P7 wild-type and weaver mice were transcardially perfused with $4 \%$ paraformaldehyde (in $0.1 \mathrm{M}$ phosphate buffer. $\mathrm{pH} 7.4$ ). After the cerebella were dissected out, postfixed in the same fixative for $2 \mathrm{hr}$, cryoprotected with a $30 \%$ sucrose solution, sagittal sections were cut at the midline portion of the cerebella using a cryostat machine. The sections were first blocked with a histomark blocking solution (Kirkegaard Perry Lab) and then incubated with a rabbit antibody against the extracellular domain of TrkB (Yan et al., 1994; anti-TrkB ${ }_{23-36}, 2 \mu \mathrm{g} / \mathrm{ml}$ ) in PBS containing 3\% normal goat serum and $2 \%$ Triton $\mathrm{X}-100$ overnight at $4^{\circ} \mathrm{C}$. A biotinylated donkey antirabbit secondary antibody and a streptavidin-horseradish peroxidase conjugate (1:200, Amersham Life Science) were used before diaminobenzidine-peroxidase reaction. The sections were then dehydrated in ascending graded alcohols, cleared in xylene, and mounted in Permount.

The TrkB antiserum was a gift from Drs. Stuart Feinstein and Monte Radeke (UCSB) and was previously characterized. It specifically recognizes purified extracellular domain of TrkB, but not TrkA and TrkC, and the immunoreactivity of the TrkB antiserum can be blocked by preincubation with TrkB peptide 23-36 (Yan et al., 1994). Immunocytochemically, it specifically labels 293 cells expressing TrkB, but not TrkA or TrkC (K. Beck, personal communication). In the present experiments, when the primary antibody was omitted, no labeling was seen on the sections.

\section{Results}

Neurotrophins do not stimulate neuronal proliferation of $E G L$ granule cell precursors in the reaggregate culture

When purified EGL precursor cells from the developing cerebellum are cultured as reaggregates, neuronal proliferation can be replicated in vitro (Gao et al., 1991). To determine if neurotrophin family members had any effects on precursor cell pro-
Table 1. BrdU labeling index of EGL cells in reaggregate cultures in the absence or presence of different neurotrophins or IGF-1

\begin{tabular}{ll} 
Cultures & Labeled cells $(\%)$ \\
\hline Control & $29.4 \pm 1.9$ \\
NGF & $29.7 \pm 3.2$ \\
BDNF & $27.5 \pm 2.1$ \\
NT-3 & $28.8 \pm 2.3$ \\
NT-4/5 & $27.2 \pm 2.2$ \\
IGF-1 & $42.4 \pm 4.6$
\end{tabular}

EGL granule cell precursors were purified from mouse cerebellum on P5-P6 and maintained in reaggregate cultures in serum-free medium in the absence or presence of $10 \mathrm{ng} / \mathrm{ml}$ of different neurotrophins of IGF-1 for $1 \mathrm{~d}$ prior to BrdI J labeling. The number of labeled nuclei was quantitated by Nomarski microscopy and is expressed as a percentage of the total cell population. For each value, a random sample of approximately 2000 cells was counted and data are expressed as mean \pm SEM.

liferation in the reaggregate culture system, DNA synthesis of the EGL granule cell precursors was measured by ${ }^{3} \mathrm{H}$-thymidine incorporation and by counting mitotic figures that were revealed by bromo-deoxyuridine (BrdU) immunocytochemistry. As shown in Figure 1, none of the neurotrophins increased the total ${ }^{3} \mathrm{H}$-thymidine incorporation by the EGL precursors at a wide range of concentrations tested (from 0.1 to $10 \mathrm{ng} / \mathrm{ml}$ ). Similarly, an equivalent number of BrdU-labeled cells, as indicated by mitotic indices of $27-30 \%$, were seen in all of the reaggregate cultures either in the absence or presence of neurotrophins (Table 1). As a positive control, when $10 \mathrm{ng} / \mathrm{ml}$ of insulin-like growth factor (IGF-1) was added to the culture, a nearly twofold increase of ${ }^{3} \mathrm{H}$-thymidine incorporation (Fig. 1; see also Gao et al., 1991), as well as a $45 \%$ increase in the BrdU labeling index were observed (Table 1 ). The results from both ${ }^{3} \mathrm{H}$-thymidine incorporation and BrdU immunocytochemistry strongly suggest that neurotrophins do not stimulate the proliferation of EGL granule cell precursors.

Neurotrophins fail to rescue phenotypic defect of weaver $E G L$ precursor cells in initiation of neuronal differentiation

Weaver EGL cells provide a good system for studying signals required for the initiation of neuronal differentiation as their proliferation occurs normally (Rezai and Yoon, 1972) but their differentiation, as indicated by neurite extension, fails (Willinger and Margolis, 1985; Gao et al., 1992; Gao and Hatten, 1993). To test whether any of the neurotrophins was able to rescue the defect of weaver granule cells in initiation of neuronal differentiation, we purified EGL cells from weaver cerebella and let them reaggregate before transferring them to a poly-D-lysine substrate in serum-free medium in the absence or presence of different neurotrophic factors. None of the four neurotrophin family members rescued the phenotypic defect of weaver cells in the initiation of neuronal differentiation. Figure 2 shows typical examples of weaver cell reaggregate cultures in the absence (Fig. 2A) or presence of NT-4/5 or BDNF (Fig. 2B,C). In contrast to the wild-type EGL cell cultures which extended a halo of neurites (Gao et al., 1992; also see below), the weaver EGL cells failed to extend neurites. Even after a longer culture time, the maximal length of neurites extended by weaver cells was still limited to $5-25 \mu \mathrm{m}$ regardless of the absence or the presence of the neurotrophins (Fig. 2). 

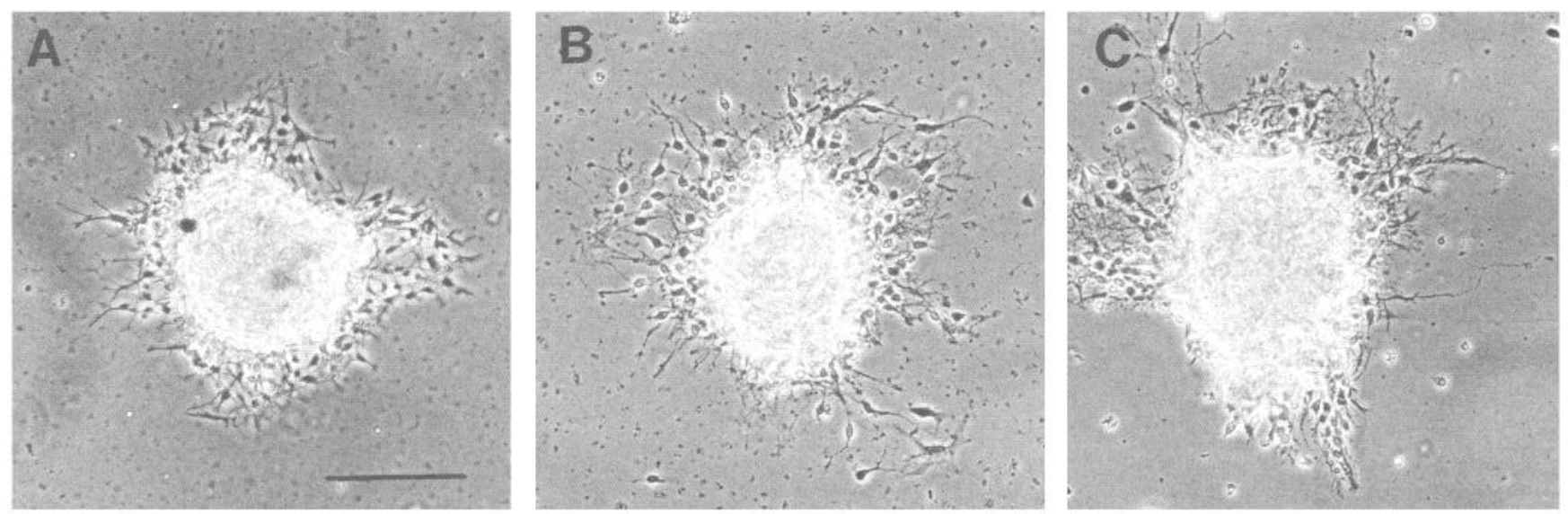

Figure 2. Neurotrophins fail to rescue weaver cell phenotypic defect in initiation of neuronal differentiation. EGL cells were purified from weaver mouse cerebellum on P5-P6 and reaggregated in serum-medium for $36 \mathrm{hr}$ before transferred to a poly-D-lysine substrate in serum-free medium in the absence $(A)$ or presence of $10 \mathrm{ng} / \mathrm{ml}$ of NT- $4 / 5(B)$ or $10 \mathrm{ng} / \mathrm{ml}$ of BDNF $(C)$. In contrast to the reaggregate culture of the wild-type EGL cells which extended a halo of neurites (see Fig. 3), neither NT-4/5 or BDNF rescued the phenotypic defect of weaver cells in neuronal differentiation. The mutant EGL cells failed to extend long neurites regardless of the absence or the presence of neurotrophins. Phase contrast microscopy. Scale bar, $100 \mu \mathrm{m}$.

\section{$N T-4 / 5$ and BDNF promote neurite extension by differentiated cerebellar granule neurons}

Previously, we showed that interactions among EGL cells induce postmitotic EGL cells to undergo neuronal differentiation initiated by outgrowth of neurites (Gao et al., 1991, 1992; Gao and Hatten, 1993). To examine the role of neurotrophins in later stages of neuronal differentiation, wild-type EGL cells, whose differentiation had been initiated by signals within the cellular EGL reaggregates, were transferred to poly-D-lysine, exposed to neurotrophins $(10 \mathrm{ng} / \mathrm{ml})$ and analyzed $48 \mathrm{hr}$ later for neurite extension (Gao et al., 1991). While NGF and NT-3 showed no effects, NT-4/5 and BDNF significantly increased neurite extension (Figs. 3, 4). When the distance was measured at both horizontal and vertical points between the perimeter of the field of neurites and the edge of the reaggregate, neurite extension by granule neurons was increased by nearly threefold in the presence of NT- $4 / 5$ or/and BDNF (Figs. 3, 4). In contrast to the reaggregate culture of weaver EGL cells (Fig. 2), neurites extended by the control reaggregate culture (without neurotrophins) were approximately $100 \mu \mathrm{m}$ long and increased in length by about $50 \mu \mathrm{m}$ per day (Fig. $3 A$ ). In the presence of NT-4/5 or/and BDNF, the reaggregates extended neurites as long as 300 $\mu \mathrm{m}$ after $2 \mathrm{~d}$ on a poly-D-lysine substrate (Figs. 3, 4). Although NT-4/5 was slightly more effective than BDNF at a concentration of $10 \mathrm{ng} / \mathrm{ml}$, statistically NT- $4 / 5$ and BDNF had equivalent effects (Fig. 4).

To determine if NT-4/5 and BDNF could have synergistic effects, both neurotrophins were added to the culture. No additive effects were observed when both NT- $4 / 5$ and BDNF were present in the culture (Figs. 3C, 4).

In addition, to examine the specificity of the neurite-promoting effects of NT-4/5 and/or BDNF, K-252a, a specific inhibitor for Trk tyrosine kinase receptors (Berg et al., 1992; Nye et al., 1992; Taplcy et al., 1992), was added to the culture. As shown in Figures $3 D$ and 4, K252a, at a concentration of $100 \mathrm{~nm}$, completely blocked the neurite-promoting effects of these two neurotrophins.

\section{NT-4/5 and BDNF promote weaver cell neurite extension after their initiation of neuronal differentiation are rescued by wild-type cells}

Previously, it was reported that wild-type granule cells can rescue the phenotypic defect of weaver cells in initiation of neuronal differentiation (Gao et al., 1992). To provide additional evidence that neurotrophins promote the maturation of differentiated granule cells, we examined neurite extension by weaver cells after their rescue by wild-type cells. When dye-labeled, purified weaver EGL cells were mixed with unlabeled, purified wild-type EGL cells in reaggregate cultures in the absence or presence of different neurotrophins, only NT- $4 / 5$ and BDNF promoted overall reaggregate neurite extension (Fig. 5). In the cultures containing $10 \mathrm{ng} / \mathrm{ml}$ of NT- $4 / 5$ or BDNF, dye-labeled neurites, extended by weaver cells in the reaggregate, were also enhanced in the same manner as the wild-type cells in these intermixed cultures (Fig. $5 D, F^{\prime}$ ), as compared to control cultures (Fig. 5B). The longest neurites extended by the weaver cells in the reaggregate reached the boundary of the halo of neurites. These results support the idea that although NT-4/5 and BDNF do not induce the initiation of EGL cell differentiation, they promote the maturation of the differentiated granule cells.

\section{$N T-4 / 5$ and BDNF promote the survival of wild-type cerebellar granule cells}

To study the possible effects of neurotrophins on maintenance of differentiated cerebellar granule cells, purified granule neurons were plated as a monolayer culture at low density $(100,000$ cells $/ 35 \mathrm{~mm}$ dish) in defined serum-free medium with or without neurotrophic factors. As cells were not in direct contact at this low density, they ceased proliferation and underwent differentiation by extending neurites. When BrdU immunocytochemistry was performed in these cultures, a mitotic labeling index of approximately $1.2-1.6 \%$ was detected regardless of the presence or absence of neurotrophins (not shown). These results indicate that DNA synthesis is minimal under this culture condition and are in agreement with the data obtained previously (Gao et al., 1991). In control cultures, more than $60 \%$ of the cells died after 

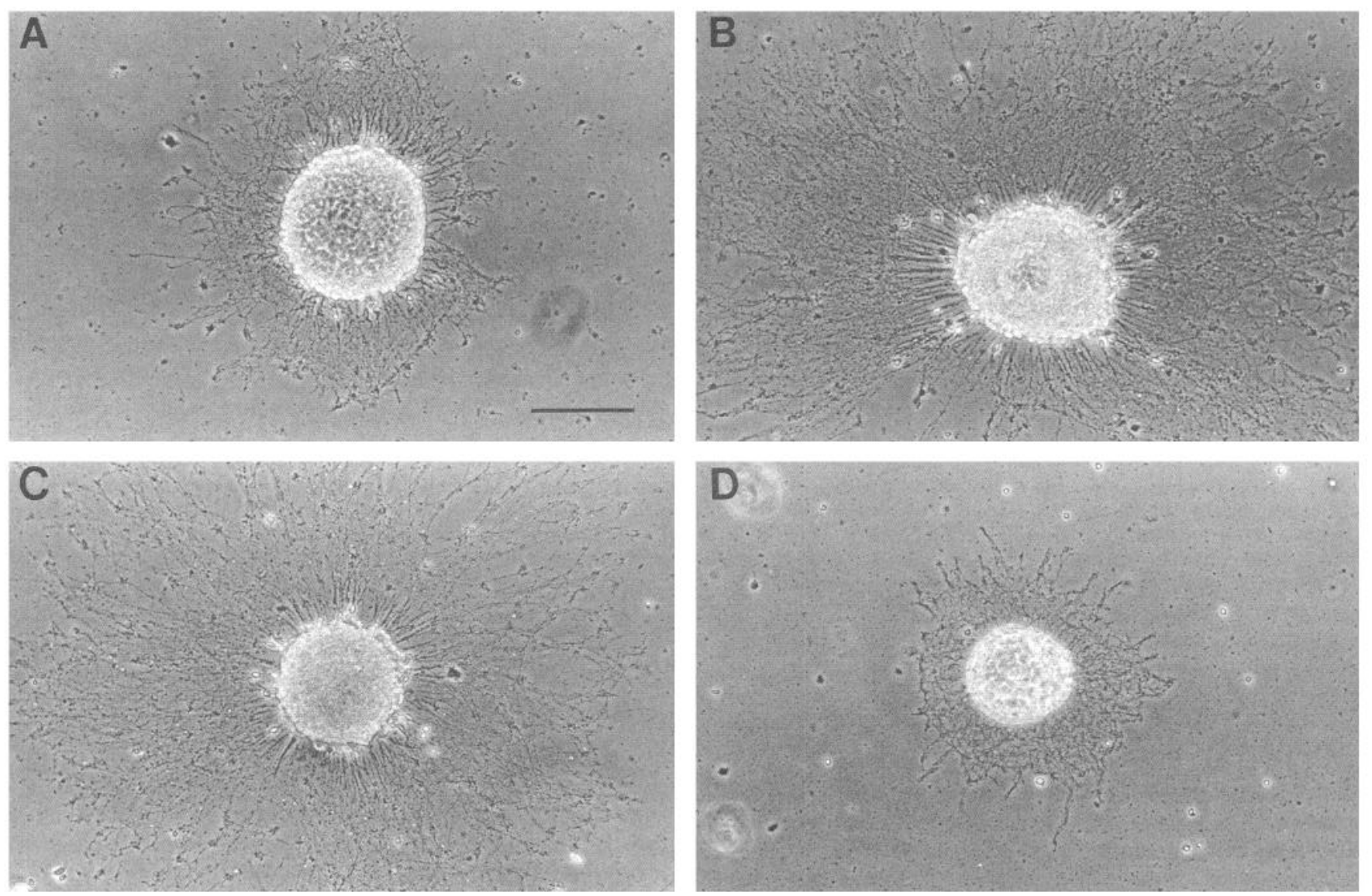

Figure 3. Neurite extension of the EGL cell reaggregates is promoted by NT-4/5 and BDNF. EGL cells were purified from mouse cerebellum on P6, and maintained in cellular reaggregates for $30 \mathrm{hr}$ in serum-containing medium, after which they were transferred to a substratum coated with poly-D-lysine $(1 \mathrm{mg} / \mathrm{ml})$ in serum-free medium alone $(A)$, in serum-free medium with $10 \mathrm{ng} / \mathrm{ml}$ of NT-4/5 $(B)$, with both NT-4/5 and BDNF $(C)$ or with a cocktail of NT-4/5, BDNF, and K-252a (100 nM) $(D)$. The cultures were assayed $2 \mathrm{~d}$ after transfer to the poly-D-lysine substratum. Whereas EGL cells in the control culture extended a small dense halo of neurites onto the culture surface $(A)$, EGL cells in the reaggregate cultures containing NT-4/5 $(B)$, or a combination of NT-4/5 and BDNF $(C)$ extended nearly threefold longer neurites. K-252a, a specific inhibitor for Trk tyrosine kinases, blocked the neurite-promoting effects of NT-4/5 and BDNF $(D)$. Phase contrast microscopy. Scale bar, $100 \mu \mathrm{m}$.

$2 \mathrm{~d}$, presumably due to a lack of trophic factors. While NGF and NT-3 had no effects, NT-4/5 and BDNF showed very significant survival-promoting effects on differentiated granule cells (Figs. 6B, $C ; 7 A$ ).

The survival-promoting effects of NT-4/5 and BDNF were dose dependent (Fig. 7A). At a concentration of $0.1 \mathrm{ng} / \mathrm{ml}$, NT$4 / 5$ was more effective than BDNF, had $60 \%$ more neurons in the culture as compared to the control. At higher concentrations ( $1 \mathrm{ng} / \mathrm{ml}$ and $10 \mathrm{ng} / \mathrm{ml}$ ), both NT-4/5 and BDNF were equally effective. The average number of granule cells in a given area increased as much as twofold in the presence of NT-4/5 or $\mathrm{BDNF}$ at a concentration of $10 \mathrm{ng} / \mathrm{ml}$ (Figs. 6, 7A). Although NT-4/5 showed a slightly better effect, no statistical difference was found between the two neurotrophins at concentrations of 1-10 ng/ml. Since the neurotrophins did not affect neuronal proliferation (see above), the increased cell number we observed with NT-4/5 and BDNF reflected a survival effect.

As seen in neurite extension assays, no additive effect of NT$4 / 5$ and BDNF was observed (Figs. $6 C, 7 A$ ). Furthermore, the specific inhibitor for Trk tyrosine kinase receptors, K252a, completely blocked the survival-promoting effects of NT-4/5 and/or BDNF (Figs. $6 D, 7 B$ ). As K252a produced a slight decrease in both neurite outgrowth (Fig. 4) and cell survival (Fig. 7B), it was possible that $100 \mathrm{~nm}$ of $\mathrm{K} 252 \mathrm{a}$ was toxic to these cells. To rule out this possibility, basic fibroblast growth factor (bFGF) $(10 \mathrm{ng} / \mathrm{ml})$, which was previously shown to promote granule cell survival (Hatten et al., 1988; Cohen et al., 1990), was added to the culture along with K252a. A $70 \%$ increase in cell number was observed in these cultures (Fig. $7 B$ ), suggesting that K252a is not toxic to the cells and confirming that $\mathrm{K} 252 \mathrm{a}$ is a specific inhibitor for Trk tyrosine kinase receptors (Berg et al., 1992; Nye et al., 1992; Tapley et al., 1992).

When purified weaver EGL precursor cells were plated as a monolayer at low density as described above, virtually all cells died within $2 \mathrm{~d}$. In contrast to the survival effects of NT-4/5 and BDNF on wild-type granule cells, none of the neurotrophins prevented weaver cells from cell death (not shown).

\section{Differentiated granule neurons, but not the EGL precursors, make high levels of TrkB receptor}

To examine the expression pattern of the high affinity receptor for BDNF and NT-4/5, the TrkB, during granule cell neurogenesis, immunohistochemistry with a TrkB antiserum (anti$\mathrm{TrkB}_{23-36}$; Yan et al., 1994) was performed on sagittal sections of P7 wild-type cerebellum containing different developmental stages of granule neuron. As shown in Figure 8, $A$ and $C$, intense 


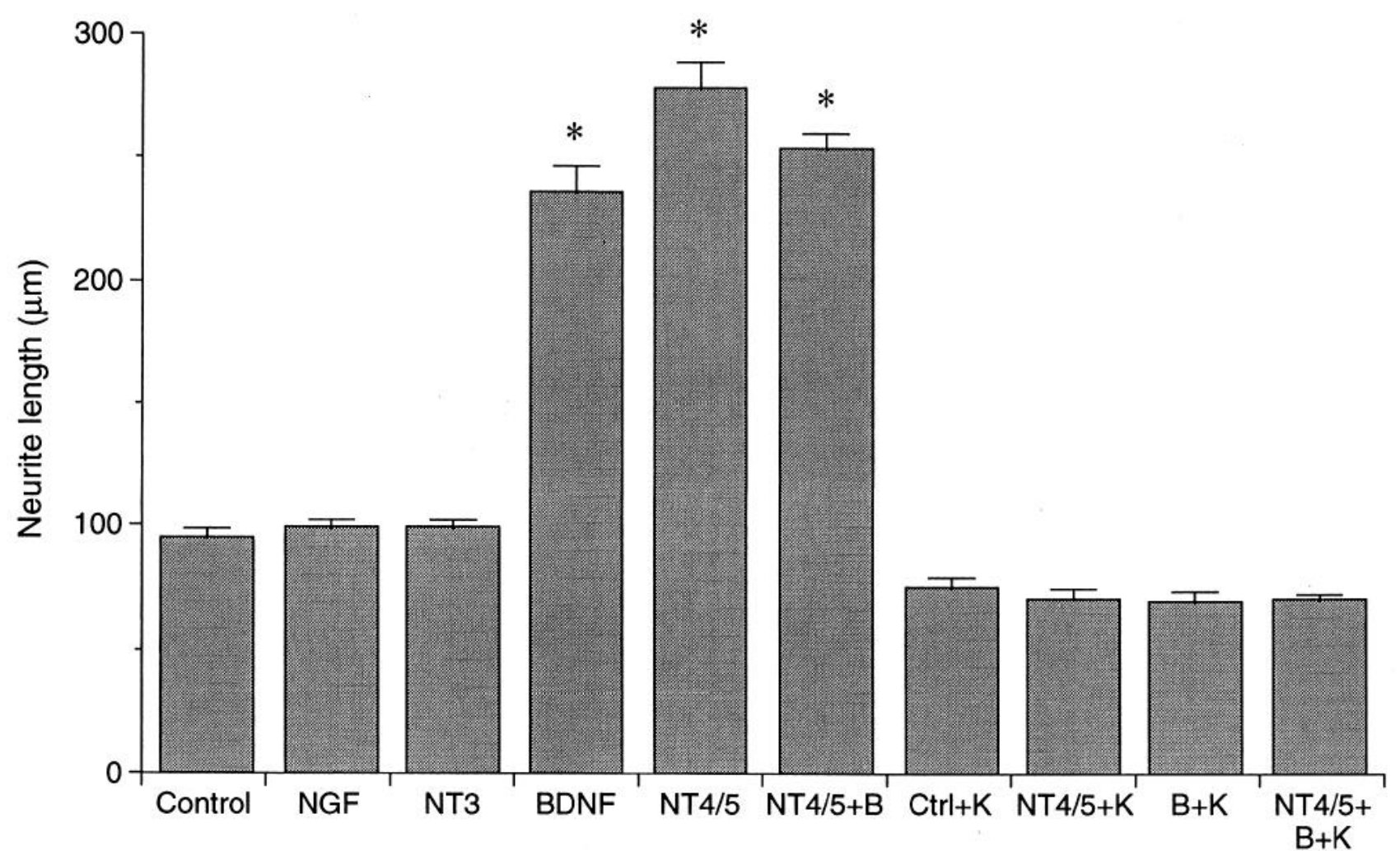

Figure 4. Quantitation of the effects of neurotrophins on neurite extension by the reaggregate cultures. For each reaggregate culture, $30-40$ randomly selected cellular reaggregates of equivalent size were measured from three to five cultures. The average distance was measured between the edge of the reaggregate and the perimeter of the neurites extended by the reaggregates. These results indicated a clear neurite-promoting effect of $10 \mathrm{ng} / \mathrm{ml}$ of NT-4/5, BDNF, and a combination of NT-4/5 and BDNF, but not NT-3 or NGF. K-252a (100 nM) blocked completely the effects of NT-4/5 and/or BDNF. The error bars are for SEM, and asterisks indicate $p<0.001$ ( $t$ test) as compared to the control culture. Abbreviations: $B$, BDNF; $K, \mathrm{~K}-252 \mathrm{a}$.

labeling was seen in the migrating granule cells in the molecular layer (ML). These migrating granule neurons had just passed the initial stage of differentiation including extension of long parallel fibers and elaboration of a leading migratory process (see Ramon y Cajal, 1889, 1911; Gao and Hatten, 1993). In contrast, the precursor cells in EGL were unlabeled. Purkinje cells (which were aligned as one layer in P7 wild-type cerebellum) as well as some cells in the internal granule cell layer (IGL) were weakly labeled. Consistent with these observations, no cells except the Purkinje neurons were weakly labeled in the P7 weaver cerebellum (Fig. 8B,D). As the weaver EGL precursor cells failed to differentiate and migrate, virtually no molecular layer and internal granule cell layer were formed in the P7 weaver cerebellum. As reported previously, the Purkinje cells were somewhat dispersed and not aligned as one layer in the mutant cerebellum (Rakic and Sidman, 1973). These results indicate that only partially differentiated granule cells, but not the dividing precursors or cells initiating differentiation, make high levels of TrkB protein, and support the model for actions of NT-4/5 and $\mathrm{BDNF}$ at the late stages of granule cell differentiation.

\section{Discussion}

In the present study, we examined the effects of four members of the neurotrophin family on cerebellar granule cell neurogenesis including neuronal proliferation, initiation of neuronal differentiation, maturation of neuronal differentiation, and neuronal maintenance. In the reconstituted EGL in vitro model, neither DNA synthesis measured by ${ }^{3} \mathrm{H}$-thymidine incorporation nor cell division detected by BrdU immunocytochemistry was stimulated by the neurotrophins. Similarly, neurotrophins failed to induce the weaver EGL cells to undergo granule cell differentiation. However, NT-4/5 and BDNF, but not NGF and NT3, promoted neurite extension and survival of the differentiated granule cells. These results strongly indicate that neurotrophins do not influence neuronal proliferation and initiation of neuronal differentiation, but as shown by NT-4/5 and BDNF, they play a trophic role on maturation and maintenance of differentiated granule neurons.

The high levels of TrkB receptor found only in differentiated granule cells in ML, but not the precursor cells in the EGL, demonstrated by immunohistochemistry in the developing cerebellum support the model that NT-4/5 and BDNF act at the later stages of granule cell differentiation. This model is also in agreement with Northern and in situ hybridization studies related to expression of BDNF mRNA, NT-4/5 mRNA, and TrkB mRNA in developing and adult cerebellum (Hofer et al., 1990; Klein et al., 1990; Maisonpierre et al., 1990; Phillips et al., 1990; Merlio at al., 1992; Rocamora et al., 1993; Timmusk et al., 1993). These studies showed that the expression level of TrkB is relatively low in the neonatal cerebellum but continues to increase progressively during the next few weeks (Klein et al., 1990). Moreover, both NT-4/5 mRNA and BDNF mRNA are expressed in the developing cerebellum (Maisonpierre et al., 1990; Rocamora et al., 1993; Timmusk et al., 1993), which implicates the role of these two neurotrophins during the development of granule neurons. The differential responsiveness of 

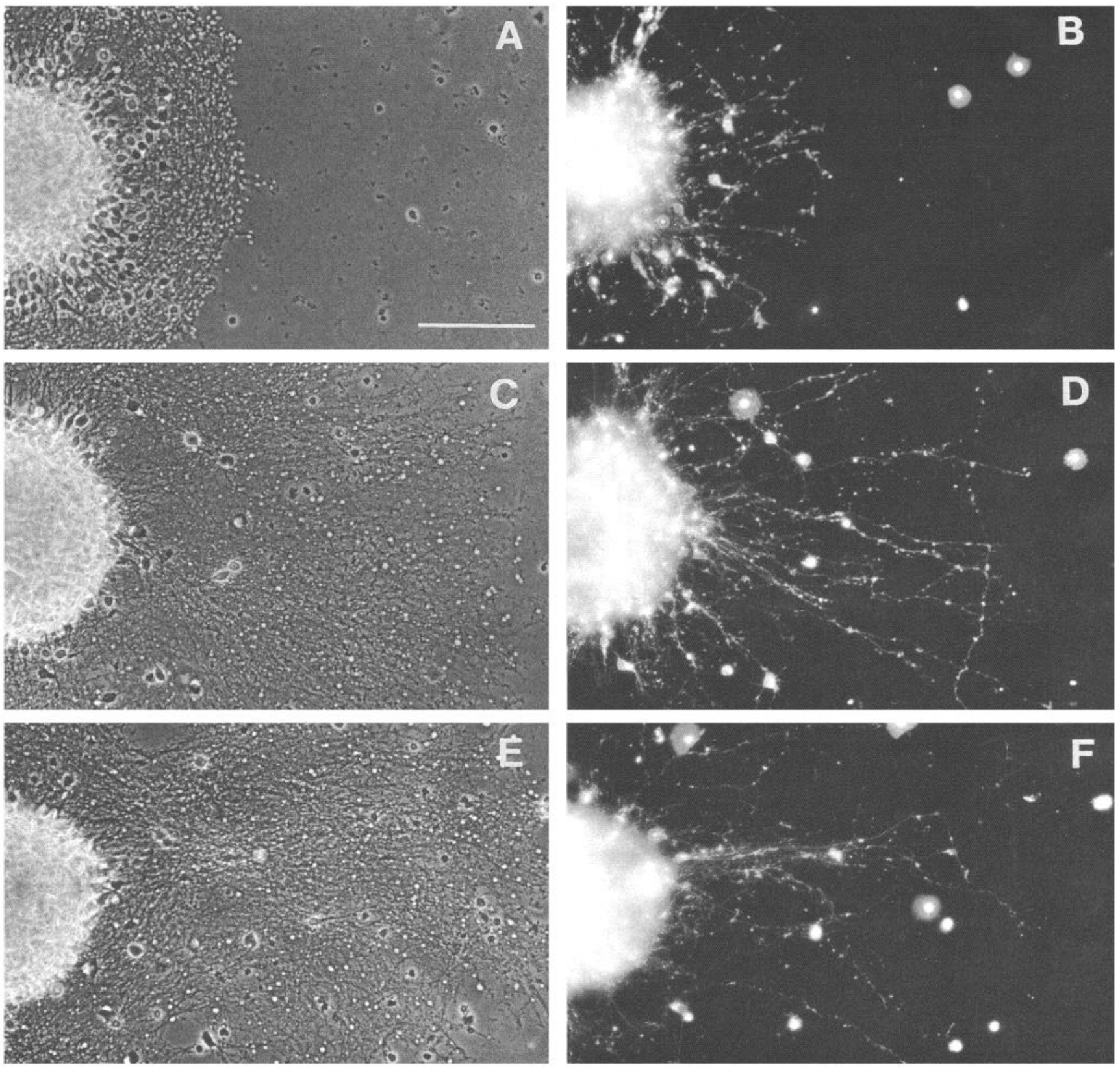

Figure 5. Weaver granule cell neurite extension is enhanced after their initiation of differentiation is rescued by wild-type granule cells in cellular reaggregates. EGL cells were purified from weaver mouse cerebellum on P5-P6 and mixed with EGL cells purified from P5 wild-type cerebellum at a ratio of 1:10. The mixed cells were then allowed to reaggregate for $30 \mathrm{hr}$ before transferred to a poly-M-lysine-coated 8 well Lab-Tek culture slide in serum-free medium without neurotrophins $(A, B)$, with $10 \mathrm{ng} / \mathrm{ml}$ of NT- $4 / 5(C, D)$, or $10 \mathrm{ng} / \mathrm{ml}$ of BDNF $(E, F)$. The reaggregates were assayed for neurite extension $48 \mathrm{hr}$ later. As described previously (Gao et al., 1992), in all cultures, weaver cells were labeled with the membranesoluble dye PKH26 prior to coculture. By phase contrast microscopy $(A, C, E)$ a halo of neurites were seen to extend from all reaggregates. Using fluorescent illumination $(B, D, F)$, dye-labeled weaver cells, as the wild-type cells, were seen to have extended about threefold longer neurites in the reaggregate cultures containing either NT-4/5 or BDNF $(D, F)$ as compared to the control culture $(B)$. Scale bar, $100 \mu \mathrm{m}$.

granule cell precursors and differentiated granule cells to NT$4 / 5$ and BDNF and special expression pattern of the TrkB receptor in the developing cerebellum therefore strongly suggest that these two neurotrophins act at later stages of neuronal differentiation, in the facilitation of neuritic arborizations and in the maintenance of these cells.

Segal et al. (1992) have previously shown that BDNF induces c-fos expression in cultured embryonic granule cells and promotes survival of these cells after $7 \mathrm{~d}$ in vitro at a concentration of $20-50 \mathrm{ng} / \mathrm{ml}$. During preparation of this manuscript, Lind- holm and coworkers (1993a) also reported that treatment with BDNF $(10 \mathrm{ng} / \mathrm{ml})$ increases c-fos mRNA and promotes survival of postnatal granule neurons in vitro. The present study is consistent with these earlier observations with BDNF. Furthermore, our experiments demonstrated the stage-specific effects of both NT-4/5 and BDNF during granule cell neurogenesis, which somewhat contrasts with results obtained with organotypic cultures of newborn rat cerebella (Segal et al., 1992). In 3 or $4 \mathrm{~d}$ organotypic cultures, BDNF at a concentration of $50 \mathrm{ng} / \mathrm{ml}$ induces c-fos-like immunoreactivity in the EGL. The simplest ex- 

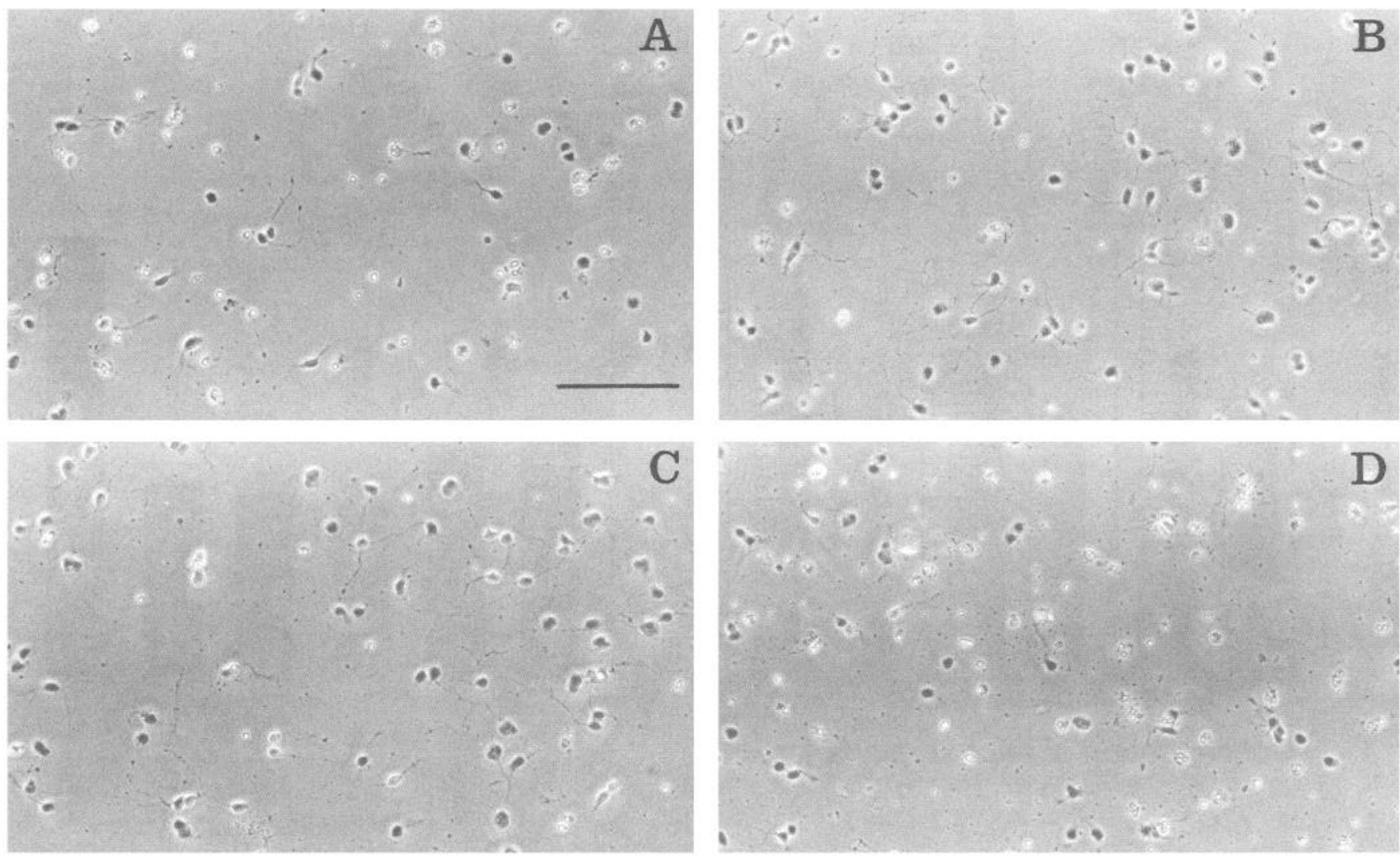

Figure 6. NT-4/5 and BDNF promote the survival of differentiated granule cells. EGL cells were purified from wild-type mouse cerebellum on P6, and plated in poly-D-lysine-coated $(1 \mathrm{mg} / \mathrm{ml})$ Nunc $35 \mathrm{~mm}$ culture dishes as a monolayer at low density (100,000 cells/dish) in serum-free medium with or without neurotrophins. In the absence of neurotrophins, more than $60 \%$ of cells died $(A)$. In the presence of $10 \mathrm{ng} / \mathrm{ml}$ of NT-4/5 $(B)$ or NT-4/5 and BDNF $(C)$, granule cell survival was dramatically enhanced. In the presence of K-252a (100 nM), the promoting effect of NT$4 / 5$ and BDNF $(10 \mathrm{ng} / \mathrm{ml})$ was completely blocked $(D)$. Scale bar, $100 \mu \mathrm{m}$.

planation for the discrepancy between our TrkB immunohistochemical staining and c-fos induction in organotypic cultures is that $\mathrm{c}$-fos responses to BDNF may result from modulators other than TrkB receptor (Squinto et al., 1991) and are secondary events. Alternatively, 3 or $4 \mathrm{~d}$ organotypic cultures may not exactly represent the in vivo situation. In the present study, data collected from experiments with both wild-type and weaver cells correlate well with the TrkB immunohistochemical staining in the developing cerebellum.

As compared to the effects of BDNF in the present experiments, we observed an equivalent or slightly stronger effect by NT- $4 / 5$ on both neurite extension and neuronal survival. In addition, no additive effect of NT-4/5 and BDNF was observed. These data suggest that the two neurotrophins act probably through the same receptor for signal transduction as both of the neurotrophins are known to bind to and induce autophosphorylation of the TrkB receptors (Berkemeier et al., 1991; Ip et al., 1992, 1993; Escandon et al., 1994). The equal potency of these two neurotrophins on neuronal survival and differentiation has also been observed in cultures of midbrain dopaminergic neurons (Hynes et al., 1994) and distinct populations of sensory neurons (Davies et al., 1993). In this light, it is interesting to note that recent RNase protection assays by Timmusk et al. (1993) indicate that NT-4/5 mRNA is expressed at higher levels than BDNF mRNA in early postnatal cerebellum (P1-P7). Although the cellular localization of NT-4/5 in cerebellar cells remains to be determined, the existence of high levels of NT- $4 / 5$ in the neonatal cerebellum and its neurite extension and survival-promoting effects on differentiated granule neurons suggest that NT- $4 / 5$ could be one of the physiological trophic factors for later stages of granule cell differentiation.

It is rather intriguing to note that although both NT-3 mRNA and Trk C mRNA, which encodes for the NT-3 high affinity receptor (Lamballe et al., 1991; Tsoulfas et al., 1993), are strongly expressed in the developing cerebellum (Maisonpierre et al, 1990; Ernfors et al., 1992; Lindholm et al., 1993b; Rocamora et al., 1993), so far no physiological effects of NT-3 on granule neurons have been identified. NT-3 has been reported to induce $\mathrm{c}$-fos expression in cultured granule neurons, but not to promote survival of these cells (Segal et al., 1992; Lindholm et al., 1993a). One of the physiological roles for NT-3 on granule neurons could be that NT-3 is involved in regulating differentiation or survival of other cerebellar neurons such as the target, Purkinje cell. For example, Lindholm et al. (1993b) have recently shown that NT-3 promotes the survival and differentiation of Purkinje cells in vitro. Support for this model comes from the additional finding that when purified Purkinje cells are cocultured with purified granule cells, the survival and differentiation of Purkinje cells is enhanced dramatically (Baptista et al., 1994).

Our observation that NGF did not show any effects on granule cell neurogenesis including neuronal proliferation, neurite extension and cell survival is in agreement with the lack of TrkA receptors on granule cells (Lindholm et al., 1993a). In the cerebellum, NGF has been reported to have an effect on Purkinje 

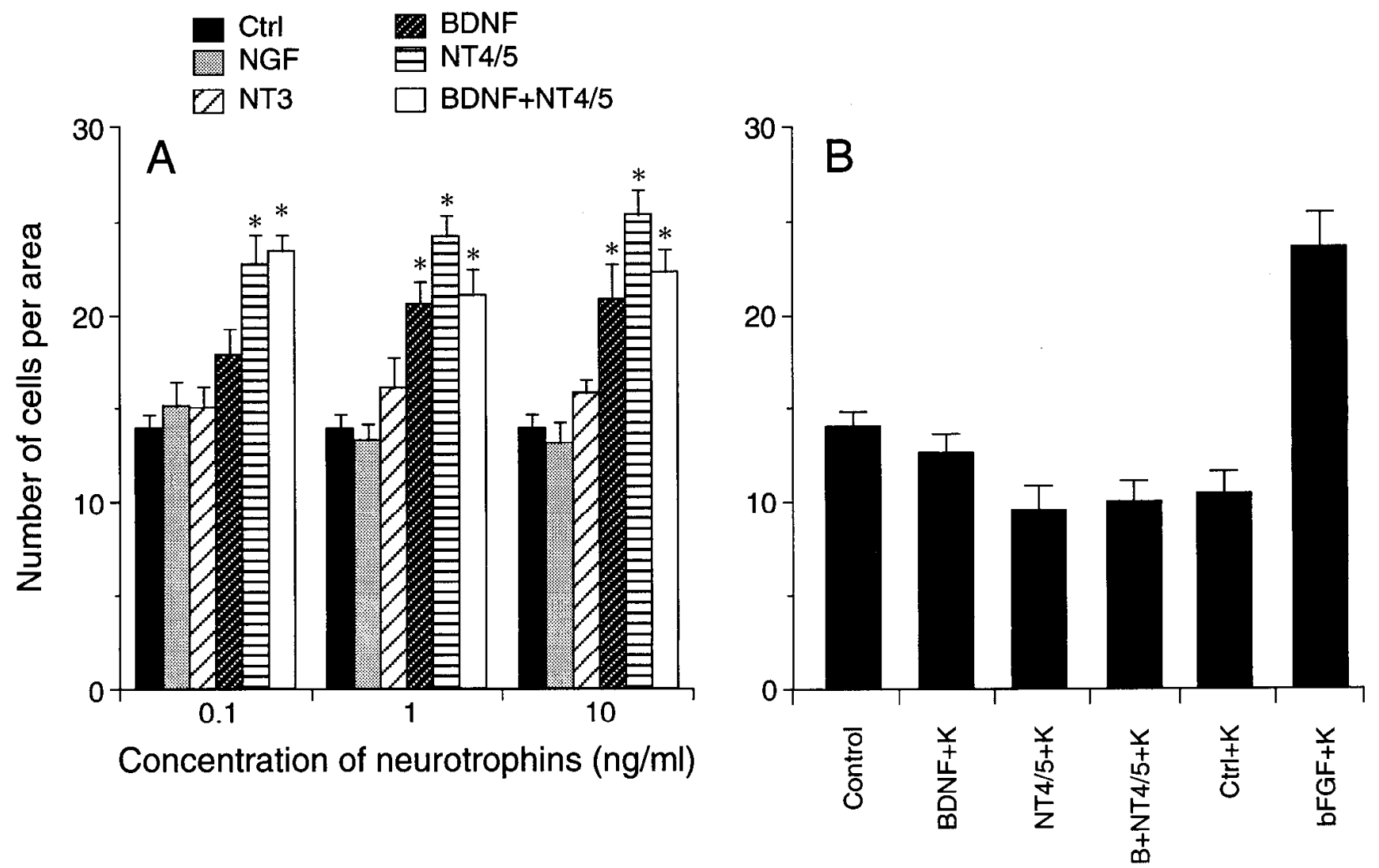

Figure 7. Quantitation of the effects of neurotrophins on granule cell survival. Data were collected from randomly selected areas in the low density, monolayer granule cell cultures containing different neurotrophins at different concentrations $(A)$, or containing $100 \mathrm{nM} \mathrm{K}-252 \mathrm{a}$ alone or along with $10 \mathrm{ng} / \mathrm{ml}$ of NT-4/5, BDNF, both NT-4/5 and BDNF, or $10 \mathrm{ng} / \mathrm{ml}$ of bFGF $(B)$. Viable cells were counted by trypan blue exclusion under a phase contrast microscope with a grid ocular reticule covering an area of $1 \mathrm{~mm}^{2}$. Three to five cultures were examined for each culture condition, and 10-20 areas were counted for each culture. The error bars are for SEM, and asterisks indicate $p<0.001$ ( $t$ test) as compared to the control culture. Abbreviations: $B, \mathrm{BDNF} ; K, \mathrm{~K}-252 \mathrm{a}$.

cell survival and differentiation in combination with excitatory neurotransmitters (Cohen-Cory et al., 1991). However, whether this will have any indirect effect on granule cell differentiation remains to be determined as these two types of cells are synaptic partners.

The heterogeneity of CNS cell cultures is usually problematic for interpretation of whether neurotrophins act directly or indirectly. In the present experiments, the cultures of granule cells wcre purificd to $99 \%$ homogeneity using morphological, immunocytochemical and ultrastructural analyses (Hatten, 1985, Gao et al., 1991, 1992). When such purified EGL cells are implanted into the developing cerebellum, all cells differentiate into granule neurons, as they all adopt their special "T-shaped" morphology, a particular laminar localization and characteristic neuritic arborization pattern (Gao and Hatten, 1994). Moreover, K-252a, a specific inhibitor for Trk tyrosine kinases (Berg et al., 1992; Nye et al., 1992; Tapley et al., 1992), blocked completely the effects of NT-4/5 and/or BDNF on neurite extension and granule cell survival. In contrast, the survival-promoting effect of bFGF was not affected by K252a. Therefore, the effects we observed represent direct and specific effects of the neurotrophins on these cells.

The finding that NT-4/5 or BDNF failed to rescue the phenotypic defect of weaver cells in initiation of neuronal differentiation and survival, supports the notion that a membranebound signal is required to induce these precursor cells to undergo the initial stage of granule cell differentiation (Gao et al., 1992). Previous in vitro studies on weaver cell differentiation (Gao et al., 1992) demonstrated that once the mutant cells are rescued by wild-type cells to undergo neuronal differentiation, their defects in expressing other neuronal genes such as TAG-1 (Furley et al., 1990), an adhesion molecule involved in neurite extension, and astrotactin (Edmondson et al., 1988; Stitt and Hatten, 1990; Fishell and Hatten, 1991), a molecule involved in the process of neuronal migration, can also be corrected (Gao et al., 1992). In the present experiments, once the weaver cells

Figure 8. Expression pattern of TrkB receptor in wild-type and weaver developing cerebella. Nomarski micrographs of TrkB immunohistochemistry on sagittal sections of P7 wild-type and weaver cerebella at low $(A, B)$ and high magnifications $(C, D)$, respectively. In the wild-type cerebellum $(A, C)$, while the migrating granule neurons (arrowheads) in ML were heavily labeled, the EGL was unlabeled. Purkinje cells (arrows) and a few cells in IGL were weakly stained. In the weaver cerebellum $(B, D)$, virtually no ML and IGL were formed as the mutant EGL precursor cells failed to differentiate and migrate. While the Purkinje neurons (arrows) which were not aligned well as one layer in the mutant cerebellum, were weakly labeled, no immunoreactivity was seen in EGL of the weaver cerebellum. $E G L$, external germinal layer; $M L$, molecular layer; $P C L$, Purkinje cell layer; $I G L$, internal granule cell layer. Scale bar: $A$ and $B, 100 \mu \mathrm{m} ; C$ and $D, 20 \mu \mathrm{m}$. 

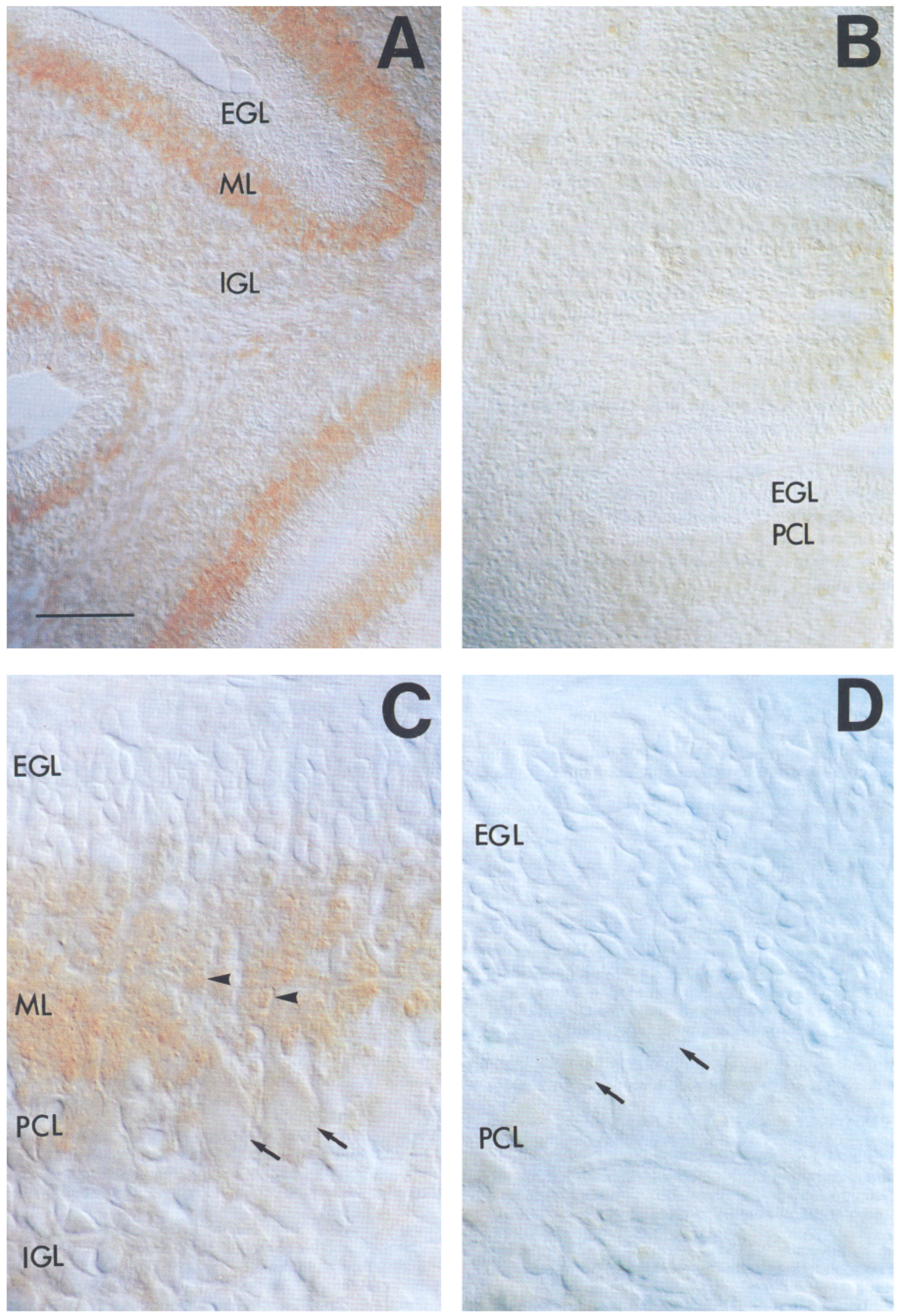
were rescued by wild-type cells during initiation of differentiation, their neurite extension was also enhanced by NT-4/5 and BDNF. Therefore, both the present and our previous experiments (Gao et al., 1992) imply that once weaver cells are rescued, they are capable of expressing subsequent neuronal genes and become responsive to other local signals in the developing cerebellum, which are responsible for later stages of granule cell differentiation. In addition, TrkB antibody labeling on wild-type and weaver developing cerebella indicates that only the differentiated granule cells, but not the EGL precursor cells, make high levels of the TrkB receptor. It is quite likely that the weaver EGI, cells that normally do not express the TrkB gene, will express high levels of TrkB gene once they are rescued by wildtype cells, as shown in the case of TAG-1 or astrotactin (Gao et al., 1992). A good example for neuronal precursors to switch from a neurotrophin-unresponsive to a neurotrophin-responsive stage has been demonstrated in an elegant study on embryonic sensory neurons (Buchman et al., 1993).

In conclusion, along with our previous studies (Gao et al., 1992), the present experiments support a model of sequential actions of neuronal genes expressed during mammalian CNS neurogenesis (Kuhar et al., 1993). While a membrane-bound signal encoded by the weaver gene is required for the initial stage of cerebellar granule cell differentiation, NT-4/5 and BDNF can act as trophic factors at later stages of granule cell differentiation, where they appear to influence the maturation and maintenance of these cells.

\section{References}

Altman J (1972) Postnatal development of the cerebellar cortex in the rat. I. The external germinal layer and the transitional molecular layer. J Comp Neurol 145:353-514.

Anderson DJ (1989) The neural crest lineage problem: neuropoiesis? Neuron 3:1-12.

Baptista CA, Hatten ME, Blazeski R, Mason CA (1994) Cell-cell interactions influence survival and differentiation of Purified Purkinje cells in vitro. Neuron 12:243-260.

Barde YA, Edgar D, Thoenen H (1982) Purification of a new neurotrophic factor from mammalian brain. EMBO J 1:549-553.

Berg, MM, Sternberg, DW, Parada, LF, Chao, MV (1992) K-252a inhibits nerve growth factor-induced trk proto-oncogene tyrosine phosphorylation and kinase activity. J Biol Chem 267:13-16.

Berkemeier LR, Winslow JW, Kaplan DR, Nikolics K, Goeddel DV, Rosenthal A (1991) Neurotrophin-5: a novel neurotrophin factor that activates trk and trkB. Neuron 7:857-866.

Buchman VL, Davies AM (1993) Different neurotrophins are expressed and act in a developmental sequence to promote the survival of embryonic sensory neurons. Development 118:989-1001.

Cattaneo E, McKay R (1990) Proliferation and differentiation of neuronal stem cells regulated by nerve growth factor. Nature 347:762765.

Cohen RN, DiCicco-Bloom E, Black IB (1990) FGF and FGF regulate mitosis of cultured cerebellar granule cell precursors. Soc Neurosci Abstr 16:804.

Cohen-Cory S, Dreyfus CF, Black IB (1991) NGF and excitatory neurotransmitters regulate survival and morphogenesis of cultured cerebellar Purkinje cells. J Neurosci 11:462-471.

Davies AM, Horton A, Burton LE, Schmelzer C, Vandlen R, Rosenthal A (1993) Neurotrophin-4/5 is a mammalian-specific survival factor for distinct populations of sensory neurons. J Neurosci 13:49614967.

DiCicco-Bloom E, Friedman WJ, Black IB (1993) NT-3 stimulates sympathetic neuroblast proliferation by promoting precursor survival. Neuron 11:1101-1111.

Edmondson JC, Hatten ME (1987) Glial-guided granule neuron migration in vitro: a high-resolution time-lapse video microscopic study. J Neurosci 7:1928-1934.

Edmondson JC, Liem RKH, Kuster JE, Hatten ME (1988) Astrotactin: a novel neuronal cell surface antigen that mediates neuron-astroglial interactions in cerebellar microcultures. J Cell Biol 106:505-517.

Ernfors P, Ibanez CF, Ebendal T, Olson L, Persson H (1990) Molecular cloning and neurotrophic activities of a protein with structural similarities to nerve growth factor: developmental and topographical expression in the brain. Proc Natl Acad Sci USA 87:5454-5458.

Ernfors P, Merlio JP, Persson H (1992) Cells expressing mRNA for neurotrophins and their receptors during embryonic rat development. Eur J Neurosci 4:1110-1158.

Escandon E, Soppet D, Rosenthal A, Mendoza-Ramirez J-L, Szonyi E, Burton LE, Henderson CE, Parada LF, Nikolics K (1994) Regulation of neurotrophin receptor expression during embryonic and postnatal development. J Neurosci 14:2954-2068.

Fishell G, Hatten ME (1991) Astrotactin provides a receptor system for glia-guided neuronal migration. Development 113:755-765.

Fujita S (1967) Quantitative analysis of cell proliferation and differentiation in the cortex of the postnatal mouse cerebellum. J Cell Biol 32:277-287.

Fujita S, Shimada M, Nakanuna T (1966) ${ }^{3} \mathrm{H}$-Thymidine autoradiographic studies on the cell proliferation and differentiation in the external and internal granular layers of the mouse cerebellum. J Comp Neurol 128:191-209.

Furley AJ, Morton SB, Manalo D, Karagogeos, Dodd J, Jessell TM (1990) The axonal glycoprotein TAG-1 is an immunoglobulin superfamily member with neurite outgrowth promoting activity. Cell 61:157-170.

Gao W-Q, Hatten ME (1993) Neuronal differentiation rescued by implantation of weaver granule cell precursors into wild-type cerebellar cortex. Science 260:367-369.

Gao W-Q, Hatten ME (1994) Immortalizing oncogenes subvert the establishment of granule cell identity in developing cerebellum. Dcvelopment 120:1059-1070.

Gao W-Q, Heintz N, Hatten ME (1991) Cerebellar granule cell neurogenesis is regulated by cell-cell interactions in vitro. Neuron 6:705-715.

Gao W-Q, Liu X-L, Hatten ME (1992) The weaver gene encodes a nonautonomous signal for CNS neuronal differentiation. Cell 68:841854.

Gratzner HG (1982) Monoclonal antibody to 5-bromo and 5-iodiodeoxyuridine: a new reagent for detection of DNA replication. Science 218:474-475.

Gregory WA, Edmondson JC, Hatten ME, Mason CA (1988) Cytology and neuron-glial apposition of migrating cerebellar granule cells in vitro. J Neurosci 8:1728-1738.

Hatten ME (1985) Neuronal regulation of astroglial morphology and proliferation in vitro. J Cell Biol 100:384-396.

Hatten ME (1987) Neuronal regulation of astroglial proliferation is membrane-mediated. J Cell Biol 104:1353-1360.

Hatten ME (1990) Riding the glial monorail: a common mechanism for glial-guided neuronal migration in different regions of the developing mammalian brain. Trends Neurosci 5:179-184.

Hatten ME, Liem RKH, Mason CA (1984) Defects in specific associations between astroglia and neurons occur in microcultures of weaver mouse cerebellar cells. J Neurosci 4:1163-1172.

Hatten ME, Liem RKH, Mason CA (1986) Weaver mouse cerebellar granule neurons fail to migrate on wild-type astroglial processes in vitro. J Neurosci 6:2676-2683.

Hatten ME, Lynch M, Rydel RE, Sanchez J, Joseph-Silverstein J, Moscatelli D, Rifkin DB (1988) In vitro neurite extension by granule cells is dependent upon astroglial-derived fibroblast growth factor. Dev Biol 125:280-289.

Henderson CE, Camu W, Mettling C, Gouin A, Poulsen K, Karihaloo M, Rullamas J, Evans T, McMahon SB, Armanini M, Berkemeier L, Phillips HS, Rosenthal A (1993) Neurotrophins promote motor neuron survival and are present in embryonic limb bud. Nature 363:266270.

Hofer M, Pagliusi SR, Hohn A, Leibrock J, Barde Y-A (1990) Regional distribution of brain-derived neurotrophic factor $\mathrm{mRNA}$ in the adult mouse brain. EMBO J 9:2459-2464.

Hohn A, Leibrock J, Bailey K, Barde YA (1990) Identification and characterization of a novel member of the nerve growth factor/brainderived neurotrophic factor family. Nature 344:339-341.

Hynes MA, Poulsen K, Armanini M, Berkemeier L, Phillips H, Rosenthal A (1994) Neurotrophin-4/5 is a survival factor for embryonic 
midbrain dopaminergic neurons in enriched cultures. J Neurosci Res 37:144-154.

Ip NY, Ibanez CF, Nye SH, McClain J, Jones PF, Gies DR, Belluscio L, LeBeau MM, Espinosa R, Squinto SP, Persson H, Yancopoulos GD (1992) mammalian neurotrophin-4: structure, chromosomal localization, tissue distribution, and receptor specificity. Proc Natl Acad Sci USA 89:3060-3064.

Ip NY, Stitt TN, Tapley P, Klein R, Glass DJ, Fandl J, Greene LA, Barbacid M, Yancopoulos GD (1993) Similarities and differences in the way neurotrophins interact with the Trk receptors in neuronal and nonneuronal cells. Neuron 110:137-149.

Jones KR, Reichardt LF (1990) Molecular cloning of a human gene that is a member of the nerve growth factor family. Proc Natl Acad Sci USA 87:8060-8064.

Klein R, Martin-Zanca D, Barbacid M, Parada LF (1990) Expression of tyrosine kinase receptor gene trkB is confined to the murine embryonic and adult nervous system. Development 109:845-850.

Klein R, Nanduri V, Jing S, Lamballe F, Tapley P, Bryant S, CordonCardo C, Jones KR, Reichardt LF, Barbacid M (1991) The trkB tyrosine protein kinase is a receptor for brain-derived neurotrophic factor and NT3. Cell 66:395-402.

Kuhar S, Feng L, Vidan S, Ross ER, Hatten ME, Heintz N (1993) Developmentally regulated cDNAs define four stages of cerebellar granule neuron differentiation. Development 112:97-104.

Lamballe F, Klein R, Barbacid M (1991) TrkC, a new member of the trk family of tyrosine protein kinase is a receptor for neurotrophin3. Cell 66:967-979.

Leibrock J, Lottspeich F, Hohn A, Hofer M, Hengerer B, Masiakowski P, Thoenen H, Barde YA (1989) Molecular cloning and expression of brain-derived neurotrophic factor. Nature 341:149-152.

Levi-Montalcini R, Angeletti P (1968) Nerve growth factor. Physiol Rev 48:534-569.

Lindholm D, Dechant G, Heisenberg C-P, Thoenen H (1993a) Brainderived neurotrophic factor is a survival factor for cultured rat cerebellar granule neurons and protects them against glutamate-induced neurotoxicity. Eur J Neurosci 5:1455-1464.

Lindholm D, Castren E, Tsoulfas P, Kolbeck R, Berzaghi MDP, Leingartner A, Heisenberg C-P, Tesarollo L, Parada LF, Thoenen H (1993b) Neurotrophin-3 induced by tri-iodothyronine in cerebellar granule cells promote Purkinje cell differentiation. Journal 122:443450.

Maisonpierre PE, Belluscio L, Friedman B, Alderson RF, Wiegand SJ, Furth ME, Lindsay RM, Yancopoulos GD (1990) NT-3, BDNF and NGF in the developing rat nervous system: parallel as well as reciprocal patterns of expression. Neuron 5:501-509.

Merlio J-P, Ernfors P, Jabcr M, Pcrsson H (1992) Molccular cloning of rat trkC and distribution of cells expressing messenger RNA for members of the trk family in the rat central nervous system. Neuroscience 51:513-532.

Miale I, Sidman RL (1961) An autoradiographic analysis of histogenesis in the mouse cerebellum. Exp Neurol 4:277-296.

Nye SH, Squinto SP, Glass DJ, Stitt TN, Hantzopoulos P, Macchi MJ, Lindsay NS, Ip NY, Yancopoulos GD (1992) K-252a and Staurosporine selectively block autophosphorylation of neurotrophin receptors and neurotrophin-mediated responses. Mol Biol Cell 3:677-686.
Patterson P (1978) Environmental determination of autonomic neurotransmitter functions. Annu Rev Neurosci 1:1-17.

Phillips HS, Hain JM, Laramee GR, Rosenthal A, Winslow JW (1990) Widespread expression of BDNF but not NT3 by target areas of basal forebrain cholinergic neurons. Science 250:290-294.

Rakic P (1971) Neuron-glia relationship during granule cell migration in developing cerebellar cortex. A Golgi and electron microscopic study in Macacus rhesus. J Comp Neurol 141:283-312.

Rakic P, Sidman RL (1973) Sequence of developmental abnormalities leading to granule cell deficit in cerebellar cortex of weaver mutant mice. J Comp Neurol 152:103-132.

Ramon y Cajal S (1889) Sobre las fibras nerviosas de la capa granulosa del cerebelo. Rev Trim Histol Norm Pathol, nos. 3, 4.

Ramon y Cajal S (1911) Histologie du systeme nerveux de l'homme et des vertebres. Paris: Maloine. Reprint. Madrid: Consejo Superior de Investigaciones Cientificas, 1955.

Rezai Z, Yoon CH (1972) Abnormal rate of granule cell migration in cerebellum of "weaver" mutant mice. Dev Biol 29:17-26.

Rocamora N, Garcia-Ladona FJ, Palacos JM, Mengod G (1993) Differential expression of brain-derived neurotrophic factor, neurotrophin-3, and low-affinity nerve growth factor receptor during the postnatal development of the rat cerebellar system. Mol Brain Res 17: $1-8$.

Rosenthal A, Goeddel DV, Nguyen T, Lewis M, Shih A, Laramee GR, Nikolics K, Winslow JW (1990) Primary structure and biological activity of a novel human neurotrophic factor. Neuron 4:767-773.

Segal RA, Takahashi M, McKay RDG (1992) Changes in neurotrophin responsiveness during the development of cerebellar granule cells. Neuron 9:1041-1052.

Sotelo C, Changeux P (1974) Bergmann fibers and granule cell migration in the cerebellum of homozygous weaver mutant mouse. Brain Res 77:484-494.

Squinto SP, Stitt TN, Aldrich TH, Davis S, Bianco SM, Radziejewski P, Furth ME, Valenzuela DM, DiStefano PS, Yancopoulos GD (1991) trkB encodes a functional receptor for brain-derived neurotrophic factor and neurotrophin-3 but not nerve growth factor. Cell 65:885-893.

Stitt TN, Hatten ME (1990) Antibodies that recognize astrotactin block granule neuron binding to astroglia. Neuron 5:639-639.

Tapley P, Lamballe F, Barbacid M (1992) K252a is a selective inhibitor of the tyrosine protein kinase activity of the trk family of oncogenes and neurotrophin receptors. Oncogene 7:371-381.

Timmusk T, Belluardo N, Metsis M, Persson H (1993) Widespread and developmentally regulated expression of neurotrophin-4 mRNA in rat brain and peripheral tissues. Eur J Neurosci 5:605-613.

Tsoulfas P, Soppet D, Escandon E, Tessarollo L, Mendoza-Ramirez J-L, Rosenthal A, Nikolics K, Parada LF (1993) The rat trkC locus encodes multiple neurogenic receptors that exhibit differential response to neurotrophin-3 in PC12 cells. Neuron 10:975-990.

Willinger M, Margolis DM (1985) Effect of the weaver (wv) mutation on cerebellar neuron differentiation. I. Quantitative observations of neuron behavior in culture. Dev Biol 107:156-172.

Yan Q, Matheson C, Sun J, Radeke MJ, Feinstein SC, Miller JA (1994) Distribution of intracerebral ventricular administered neurotrophins in rat brain and its correlation with Trk receptor expression. Exp Neurol 127:23-36. 